\title{
The Victory of Pluralism: The Role of International Law in The South China Sea Dispute
}

\author{
Verdinand Robertua Siahaan* \\ verdinand.robertua@gmail.com
}

\begin{abstract}
This research discussed the role of Permanent Court of Arbitration's decision on the dynamic of South China Sea dispute. Court's decision in July 2016 to regulate South China Sea based on UNCLOS's regulation has provoked China's objection. This research question is on how to understand the role of international law in the South China Sea dispute using English School Theory. To answer the research question, this research is using English School Theory with its two pillars namely pluralism and solidarism. This research shows two findings. First, the PCA decision has been used by the Philippines to be momentum for transformation from solidarist mode of foreign policy to pluralist mode. Secondly, the pluralism pillar of English School is more relevant in analyzing the role of international law on South China Sea Dispute. Key words: English School, international law, Permanent Court of Arbitration, pluralism, solidarism, South China Sea
\end{abstract}

\begin{abstract}
Abstrak
Penelitian ini membahas peran Permanent Court of Arbitration (PCA) di dalam resolusi konflik Laut Tiongkok Selatan (LTS). Keputusan PCA yang menggunakan UNCLOS sebagai tata kelola LTS memprovokasi kemarahan Tiongkok. Pertanyaan penelitian ini adalah bagaimana memahami peran hukum internasional dalam konflik Laut Tiongkok Selatan menggunakan teori English School. English School dengan kedua pilarnya pluralisme dan solidarisme menjadi pisau analisis utama untuk menjawab pertanyaan penelitian. Penelitian ini menghasilkan dua kesimpulan. Pertama, keputusan PCA digunakan sebagai Filipina sebagai momentum transformasi kebijakan luar negeri Filipina dari solidarisme menjadi pluralisme. Kedua, pilar pluralisme lebih relevan menjelaskan peran hukum internasional dalam sengketa Laut Tiongkok Selatan.
\end{abstract}

Kata kunci: English School, hukum internasional, Laut Tiongkok Selatan, Permanent Court of Arbitration, pluralisme, solidarisme

\section{Background}

South China Sea is one of the world's most dangerous conflict area. Six claimants' states including China fights for control over numerous small land features and resource-rich waters, with the United States also heavily involved because of alliances and their security and economic goals. China, Vietnam, and the Philippines have been aggressive in recent years, but China has been especially bold in staking out very broad claims to sovereignty and related rights to land and waters history in the South China Sea. China has started his project of land reclamations that build on land

* Correspondence: International Relations at the Faculty of Social and Political Science of Christian University of Indonesia, Jl. Mayjen Sutoyo 2 Cawang Jakarta 13630. 
features, turning the water into physical structures and threatening conflict escalation. Paul Gewirtz (2016) said that China's naval presence and capability have increased significantly and added concerns among China's weaker neighbors such as Vietnam and the Philippines as well as the United States, whose military presence has greatly contributed to peace and stability in the Asia-Pacific for decades. The risk of accidents or small conflicts leading to war is increasing.

The Philippines initiated law suit against China using United Nations Convention on the Law of the Sea (UNCLOS) dispute settlement framework in 2013, provoked by China's persistent claim over the Scarborough Shoals, a series of reefs between the western Philippines and the Spratly Islands. The Philippines based its claims upon sovereign rights and jurisdictional entitlements found in the 1982 United Nations Convention on the Law of the Sea which it had ratified in 1994 and China ratified in 1996. Based on UNCLOS, states's maritime entitlements are located 12nautical-mile territorial sea and 200 mile EEZ and continental shelf.

The Philippines had legal rights in initiating these complaints as a result of the compulsory dispute resolution procedures available under Part XV of UNCLOS, which allow for both judicial settlement before standing courts and arbitration before an ad hoc tribunal specially convened to hear the dispute. Under Annex VII the Philippines chose arbitration with five-member panel with the Philippines and China can nominated its preferred panel member.

Responding to this move, China didn't give legal legitimacy to the Philippines legal initiative. China wanted to solve this issue without legal mechanism. Because China rejected the court, then the President of the International Tribunal for the Law of the Sea, who at the time Judge Yanai selected the remaining arbitrators (Rothwell, 2016). Despite China's rejection of the legal legitimacy of the Philippines move, the court started its meeting under the default mechanisms of UNCLOS. Rothwell (2016) noted that the consequence of this decision was that the Philippines bore all of the institutional costs of the Arbitration, including payment of the fees of the Arbitrators.

Despite China rejected the court, the Tribunal decided it had jurisdiction due to the legal arguments that this was a critical issue for the sea border management. The Tribunal stipulated that China's claim of nine-dash line has overlapping with the 
exclusive economic zone of the Philippines and therefore the Tribunal has the jurisdiction to consider the dispute. As we know, China and the Philippines are signatories of UNCLOS and agreed that exclusive economic zone lies 200 miles from continental shelf. However, nine-dashed lines challenges this ruling and therefore the Tribunal has legal rights to consider the dispute.

After lots of hearing and meeting, the Tribunal stipulated that there was no legal basis for China for the nine-dash line, that none of the relevant maritime features in the South China Sea were Chinese islands but rather UNCLOS Article 121 (3) rocks entitled only to a territorial sea, that China's land reclamation activities and building of artificial islands infringed the environmental rights of the Philippines, and that China had tolerated environmentally damaging economic activities.

\section{English School Perspective}

For English School theorist, South China Sea dispute represented the conflict between pluralism and solidarism, two unique concept of English School showing the constant dilemma of states in navigating their foreign policy. According to Buzan $(2004,46)$, English School's pluralism represented the realism perspective of rationalism. The aim of pluralism, like realism, is about the survival of state sovereignty under the structural anarchic of International Relation. Buzan $(2004,46)$ said "they [pluralism] presuppose that states are de facto the dominant unit of human society, and that state sovereignty means practical legal and political primacy".

Meanwhile, according to Nicholas Wheeler (2000), point of departure of solidarism is the glaring contradiction between the moral justification of pluralism and the actual human rights practices of states. In his book "Saving Strangers: Humanitarian Intervention in International Society", he showed on how many states failed to protect the basic rights of their citizens. Humanitarian intervention, for Wheeler (2000), exposes the conflict between order and justice which both of them are having equal normative priority and therefore created a constant dilemma for states. Order would be nicely represented by the pluralism meanwhile justice would be championed by the solidarism. Wheeler (2000, p. 38) explained: 
"Solidarism is committed to upholding minimum standards of common humanity, which means placing the victims of human rights abuses at the centre of its theoretical project, since it is committed to exploring how the society of states might become more hospitable to the promotion of justice in world politics. Thus, changing the referent from state motivations to victims of state power leads to a different emphasis on the importance of motives in judging the humanitarian credentials of intervenors."

The pluralism and solidarism distinction within the English School aims to discover the complexity of International Relations. English School scholars believed that there is no single truth that is able to explain the contradiction and the complexity of International Relations. As Andrew Hurrell $(2007,9)$ said, the five component of pluralism namely war, the balance of power, international law, diplomacy and the great power can't satisfy to explain the far-reaching changes in the scope and range of International Relations. Hurrell $(2007,12)$ further emphasized the need for both solidarism and pluralism understanding by saying:

The structural conditions associated with globalization, the changed nature of security challenges, and the very diverse but expansive normative aspirations embodied in powerful political forces (both state and non-state) make it very difficult to accept the prescriptive bottom line with which Hedley Bull ended The Anarchical Society in 1977: that a thin pluralist international society of states provides the best available means of upholding world order.

\section{The Pluralism Side of South China Sea Dispute}

China immediately denounced the PCA ruling as null and void with no binding effect on China and lacked the jurisdiction to rule due to the absence of mechanism to enforce the decision. (The Washington Post, 2016). Lu Xiaoming (2016) called the decision as a political farce. Xiaoming (2016) said that the PCA decision can't be categorized as international law due to four criteria. Firstly, PCA didn't have jurisdiction over the subject. PCA should discussed the maritime border but the PCA ruling are about sovereignty that is beyond the PCA's jurisdictional capability. Second, the judges were not impartial that the judges haven't any expertise and background on Asian history and politics. Lastly, the procedure were not reasonable. PCA didn't respect China as sovereign country by proceeding the trial without Chinese participation. Lastly, the ruling on the substantive issues didn't help resolve the 
disputes. Xiaoming believed that the ruling created more harm than the benefit for regional order.

Responding the PCA ruling Ashley Townshend (2016) said that China will not respond to PCA with military means. However, Townshend believed that further military drills in South China Sea were possible as well as the establishment of an air defence identification zone. After Donald Trump become the US President, the situation was changing. Trump repeatedly accused China as territorial aggressor in Asia by taking South China Sea. Chinese officials were very angry and threatened to prepare large-scale war (Guardian, 2017). This confrontational approach was an indication that great power management was the solution for territorial dispute. China's rejection shows on how the absolute truth of international law is not binding. China is a great power and international law can be modified into the interest of great power.

The use of power is better seen through pluralist perspective. Morality is not part of the pluralist vocabulary. From the case of South China Sea, international law is not complied due to its conflictual relationship with the interest of great power. China needs to claim South China Sea due to its potential for energy source and security of its international trade. This article agrees with Sara Hsu (2016) who mentioned that China's own energy production has reached its peak and China is looking for alternatives for China's energy supply. The South China Sea is believed to have 11 billion barrels of oil and 190 trillion cubic feet of natural gas (Ünver, 2016). Sara Hsu (2016) noted that China's decision to begin drilling in this region in 2014 has sparked protests from Vietnam.

Not only about energy resources, China wanted to secure the access of South China Sea for its trade. Most of energy for China comes from the Sea and the containers must pass East China Sea or South China Sea. Cáceres (2014) noted that the safe passage of inputs through these waters are the Chinese national interest however these waters are not controlled by China. Cáceres called this dilemma as Chinese strategic vulnerability. If there is interruption on this passage, Chinese economies will be at risk. Daniel Yergin (2006) also concluded that South China Sea is crucial part of Chinese energy security. China relies on energy import for most of their industrial expansion need and 50\% of the oil and gas import through the South China Sea. Disruption on the waterways will risk the Chinese overall economy. 
The pluralist perspective is very visible in China foreign policy. Cáceres (2014) concluded that China's world-wide search for energy and resources is devoid of moral consideration. China welcomed cooperation with oppressive leaders or weak states in exchange for contract for energy supply. This policy is against the Western interest that punished the rogue states leaders and undisciplined governments. For China, secured energy supply for running its economy and sharing prosperity is more critical that normative consideration.

\section{The Solidarism Side of South China Sea Dispute}

Feng Zhang build an interesting solidarism analysis on the award. Zhang (2016) argues that China has softened their ambition to lowered degree and changing the rivalry with the claimant states to a coexistence position. Based on Zhang's observation on Chinese official documents responding the PCA decision, Zhang is optimistic that China will be in line with the UNCLOS regime and followed the PCA arbitration.

The impact of international law as confidence-building measure is doubtful. The role of international law in the South China Sea is undermined by the power politics approach. The ruling didn't create any barrier for China to continue their reclamation project.

The defiance of international law can be defined as complete and unceasing refutation of the judgement by taking action against the court and challenging the legitimacy of the court. According to Heather L. Jones (Jones, 2012), there are four reasons for compliance for international law consisting of external political influence, internal need for a definitive solution, the substance of the judgement issued, and internal political influence.

PCA ruling can't be complied without the political pressure from the United States and the European countries. In responding the ruling, United States didn't show tangible support for the implementation of the ruling and the European Union was not united in challenging the China's contrary decision against the ruling.

From the Chinese perspective, United States engagement with Asian country in the case of South China Sea has hampered the peaceful negotiation on the dispute. United States' rebalancing approach in 2010 has been seen as the threat. The 
United States' military activities in the South China Sea is seen as a way to outsmart China economic power.

Meanwhile, there isn't internal need for a definitive solution. 2002 Declaration of Conduct with ASEAN countries was obsolete and the initiative for Code of Conduct is neglected. There is yet any positive progress on the finalization of ASEAN's Code of Conduct of South China Sea.

The substance of the PCA judgement clearly give victory to the Philippines. This victory created anger from Chinese public opinion. In this aspect, the PCA has neglected the historical rights of South China Sea. The absence of middle way approach in this legal dispute has become the main weakness of this PCA ruling.

Lastly, the internal political influence. PCA's decision gave victory to the anti-international law group. Zhang (2016) described that there are three groups competing for influence in Chinese foreign policy: the realist, the moderate and the reformist. The realist got strong boost after the decision and the reformist was handicapped looking the full victory of the PCA decision to the Philippines.

ASEAN was not united in responding the PCA ruling. Indonesian Minister of Foreign Affairs issued a statement that all countries have to respect the PCA ruling meanwhile other ASEAN countries excluding the Philippines and Vietnam didn't issue any statement (The Jakarta Post, 2016). The disunity of ASEAN in South China Sea is understood due to the huge economic interest of China within the region (Dupont, 2014). China is a very important investor for ASEAN economy and escalating the conflict means a threat to regional order. It's not simply a territorial dispute but also an economic and trade complexity.

Andrew Hurrell (2007) believed that there are huge opportunity for solidarism to explain the complexity of international law. It is not as simple as states followed international law if it conform to their interest however states can conform their interest to international law. Secondly, even states violated the international law, states need to give an explanation of their policy.

China didn't leave the PCA ruling in a vacuum. Joseph Klein (2016) argues that PCA has made denial toward the rights of China in South China Sea. Klein said that the UNCLOS gave an opportunity for China in claiming South China Sea based on the historical rights. China has official historical documents showing the legitimacy 
of China in South China Sea. Second Klein's defense is that South China Sea is not high sea as stated by the PCA. Klein (2016) explained:

The South China Sea is a semi-closed sea, adjacent to the open ocean, extending from northeast to southwest connected by narrow straits and waterways with the Pacific Ocean to the east and the Indian Ocean to the west. It was partially enclosed by islands and archipelagos before UNCLOS came into effect and remains so today. UNCLOS has a separate Part IX entitled "Enclosed or SemiEnclosed Seas," which it defines as "a gulf, basin or sea surrounded by two or more States and connected to another sea or the ocean by a narrow outlet or consisting entirely or primarily of the territorial seas and exclusive economic zones of two or more coastal States.

By claiming South China Sea as semi-enclosed sea or enclosed sea, China has rights to claim the whole South China Sea. Solidarist argues that this explanation has crippled the notion of aggressiveness of great power in dominating the small power. If China believed that international law must confirm to the national interest, why China spend their energy to give explanation on their legitimacy of South China Sea. The willingness of China in discussing openly the legitimacy of the PCA ruling and nine-dash line and considering the legal argument of PCA indicate the importance of international law for China.

International law should not be defined strictly on the compliance. For solidarist, the obligation of states in complying the international law lies on the dialogue and the debate regarding the law. Rooms and spaces for debate and criticizing the law is an indicator of the implementation of international law as norms and ideas. Having the open definition of international law, the disagreement on the substance of certain ruling is not crippling the need of international law.

The application of national law into international law is not the idea of English School. International Relations has the complexity that the domestic politics doesn't have. The basic assumption of English School is the disagreement toward the domestic analogy. When individuals violated the traffic lights, police can catch and punish them. When states violated the international law, there is no police available for punishment. It doesn't mean that International Relations is a chaotic condition. As mentioned by Barry Buzan (2004), International Relation can be classified as secondorder society. Second-order society is society that doesn't consist of individual human- 
being but durable groups of individuals possessed identities, qualities and behaviour that are different and more than sum of their parts $(2004,26)$.

Solidarist believed that international law is important for states. Despite they are in rivalry interaction, states still need international law. Yasuaki (2003) mentioned that international law can be used as communication media. The decision of PCA is not only used for normative statements but also a form of communication between conflicting states. In the context of South China Sea case, the PCA ruling is another dialogue extension between China and other claimant states. Despite China rejected the ruling, China still maintained the diplomacy and economic relationship with the Philippines and the Vietnamese. It is very difficult to achieve agreement in territorial dispute but it is common and feasible for mutual agreement on the exportimport contract, joint flight services or sea navigation. The conflicting interest of the claimant states didn't obstruct the compliance to mutually beneficial areas of cooperation. International law become a language and structure for argumentative exchange between states.

\section{The Victory of Pluralism: The Crisis of International Law}

Philippine new president Rodrigo Duterte bring significant change on the Philippine foreign policy on South China Sea. Beniqno Aquino III, the predecessor of Duterte, was very serious using legal instruments in solving the territorial dispute (Kipgen, 2017). Aquino also used international organizations such as ASEAN and United Nations to clarify the status of South China Sea.

However, Duterte gave China a compromise on the ruling and not considered the PCA ruling in the bilateral talks with China. Rivalry with China due to the PCA ruling will be changed into business cooperation hoping China will bring significant investment to the Philippines. Duterte said that Philippines military power is not capable against China and the Philippines has to take a pragmatic steps by allowing China to claim the South China Sea (Kipgen, 2017).

Reuters (2017) reported that China threatened a war with the Philippine if the Philippine started to implement the ruling. Duterte said that he wanted to raise the arbitration ruling without jeopardizing the plan of billions of dollars in Chinese loan and infrastructure investment. In his official trip to China, Duterte brought huge 
business delegation to sign a wide-ranging series of bilateral trade and investment deals. Duterte also got Chinese financial assistance to build hospitals and rehabilitation centers supporting his war on drugs. Richard Javad Heydarian (2016) called this policy as Duterte's pivot to China.

Legitimacy of international law is undermined by the Manila's dependency to Beijing. It become a puzzle on how to solve the conflict between Manila and Beijing. Solidarism has failed to explain the Duterte policy that Manila prefers economic and business talks than the ratification and adaptation of PCA ruling. Even more, South China Sea dispute is not a priority for the Manila to discuss with China because it can hampers the economic and business talks.

The international political economy of South China Sea is very clear. When Aquino was seriously bringing South China Sea in the Philippine foreign policy, China stopped the business talks and even harmed the Philippine business community. After Duterte take out the South China Sea issue in the Philippine foreign policy, many business deals were signed. The factor of material interest is very clearly seen in Duterte's change in South China Sea. When Duterte wanted to bring back the issue, China canceled all plan for business contract.

This is clearly a dilemma. Aquino and Duterte has different policy answering this dilemma. Aquino prefers a balanced talk between conflict and cooperation meanwhile Duterte choose to avoid the conflictual relationship by taking out the sensitive issue out of the table. We need to understand the Duterte's move to focus on material achievement. Hurrell's opinion on inequality in International Relations can be applied to this case. He said:

Inequality means that some states have far less need for the cooperation and forbearance of others, that the strength of the violators of law can easily come to exceed that of the upholders of law, and that, even if this is not the case, attempts at coercive sanctions against violators will involve large-scale conflict. On this account, then, the structure of power and interests and the extent of inequality will often make the resolution of many conflicts difficult, if not impossible. All politics, but especially world politics, is the arena for struggles amongst differing social and political ideals, and the character of competition for power between these rival views and the manner in which power is deployed will remain a - but not necessarily the — central focus of enquiry (Hurrell, 2007, p. 30) 
Based on Hurrell's opinion, Manila has more reason to achieve cooperation with China due to the power inequality between Manila and Beijing. International law become less relevant in solving the territorial dispute between Manila and Beijing. War become a weak point for the powerless and international law can't help the powerless to be empowered against the great power. The characteristic of China as great power made the notion of equality and justice less relevant. Solving the conflict with great power, in Hurrell's opinion, need to consider the power equality calculation. This is the philosophical explanation of pluralism: power politics is the most convincing resolution strategy.

This thesis revised the Barry Buzan's second-order society that focused on the potential of international order in the anarchical International Relation. The second-order society emphasized that states will not be turned to be wild animal that killed other animal in a lawless situation. States will not be wild because states have their own wisdom of peace and cooperation. States is the sum of the individuals and the decision of states to fight will be the decision of all individuals. It means that the decision of rivalry is the most difficult decision because it is assumed that majority of individuals prefers peace and cooperation.

It turned wrong in the South China Sea. China is very aggressive on South China Sea issue constantly and using all power mechanism to make sure the control of South China Sea. There is lack of chance and opportunity to let other countries claiming South China Sea. The morality advised by international law is not the option for Chinese foreign policy. Interestingly, this situation is supported by Chinese internal society. The conflictual relationship is the decision of all individuals within the state. There is lack of dissenting voice of the Chinese population to against the conflictual scenario on South China Sea. The solidarism' second-order society is failed to prevent the aggressiveness of states.

From the perspective of the Philippines, the option is very limited. The United States was supposed to campaign the implementation of PCA ruling by empowering the judicial organ of PCA in order to enforce the ruling. The Philippines know that they are not able to enforce the ruling due to the power inequality. The Duterte's business talks is just a buying-time strategy in overcoming the Chinese aggressiveness in making sure the status of South China Sea. If the cooperation is not 
taken, Duterte will face serious punishment and difficult situation both in internal politics and international politics. The focus of Duterte is not taking the material incentives but making sure the Philippines is safe and strong in being defensive toward China.

The transformation from solidarism situation in Aquino foreign policy to pluralism situation in Duterte foreign policy reflects the nature of International Relations as dynamic and mutable. For liberalism, international law is an essential component of International Relation and it is immutable. It means that there is no room and opportunity for leaders to change from international law to lawless situation. The similar approach is taken by the realism. There is no room for change from anarchical situation into lawful order similar to national order. English School scholars believes that there is a two different situation that can be taken by states and the transformation from extreme-to-extreme is possible and reasonable. International Relations is filled by constant uncertainty and it is the role of researcher to grasp and describe the movement of government position from time to time.

Duterte new policy indicated a new form of pluralism. In the words of Martin Wight (1992), pluralism showed a reality, not an imagination. Pluralism shows a way of inductive thinking, taking decisions based on what we see. Martin Wight (1992, p. 17) says that pluralism concentrates on the actual, rather than the ideal, or what supposed to be, facts are better than obligations. In the case of South China Sea, the focus is now on the power inequality between Manila and Beijing. We define the policy based on the power inequality and think about the right measures on the power inequality.

It doesn't mean pluralism neglect the idea of international law. International law is indeed important in International Relations and states complied with international law most of the time. Hedley Bull (1977, p. 132) said that the violation of particular rule usually takes place in parallel for conformity to the other rules of international law. In the case of PCA ruling, China's rejection of the ruling is in parallel with China's conformity to UNCLOS regime of Part IX advising South China Sea as semi-enclosed sea. This argument emphasized that the notion of pluralism prioritizing power calculation then international law. International law is set to response the reconfiguration of power calculation. Bull $(1977,133)$ said: 
The denigrators of international law, however, while they are wrong when they claim that international law is without efficacy, are right to insist that respect for the law is not in itself the principal motive that accounts for conformity to law. International law is a social reality to the extent that there is a very substantial degree of conformity to its rules; but it does not follow from this that international law is a powerful agent or motive force in world politics.

For pluralist, the effectiveness of PCA ruling will be based on three factors. Firstly, China need to internalize the significance of the ruling to the China national interest. To implement PCA ruling should be viewed by China as mandatory, valuable and obligatory. The internal politics of China should be dominated by the reformist who keen on upholding the international law. Second, United States must be serious in giving pressures to China to respect and comply with PCA ruling. Bull said that compliance may result from coercion by the great power bent on enforcing the agreement. Bull $(1977,134)$ named this situation as the international law of power. Third reasons is that Beijing and Manila find reciprocal motives in solving the territorial dispute. Despite it may seem difficult, Duterte has showed his willingness to barter the South China Sea with equal economic deals. If it works, this is international law of reciprocity (Bull, 1977, 134).

The victory of pluralism doesn't mean that Duterte, Xi Jinping and other national leaders are pluralists. The victory of pluralism in the South China Sea is a case emphasizing the role of theory to uncover the complexity of an international issue. It is very difficult to know what really motivates decision-makers behaved and decided in a certain way. Using the pluralism and solidarism debate can lead us to see different worlds that can be starting points for the analysis of world politics. Pluralism indeed has its advantages and weaknesses in understanding the efficacy of PCA ruling. However, the solidarist has failed in bringing reasoning supporting the primacy of international law over the power politics. The presence of international law is not seen as sacred in the case of South China Sea.

We can identify that the reverse process of legalization is now happening. The legalization concept advised the process of transfer from diplomacy to international court, from vague principles to precise highly elaborated rules and from expressly non-legal norm to binding rules (Abbot, et al., 2006). We see the recent 
phenomena of the reverse; from international court to diplomacy, from precise highly elaborated rules to vague principles and from binding rules to expressly non-legal norm. This reverse process is siding to pluralism assumption. Pluralist is able convincingly explaining this reverse process.

This continuum of solidarism and pluralism will uncover many middle point that is the characteristic of English School. Uncovering pluralism in the South China Sea will not neglect the presence of solidarism and learning this continuum hopefully brings us closer to new concepts lies within the continuum. For example, John Nieves (2012) calls China as humble hard power. China, according to Nieves, should play nonmilitary means such as sea patrol, humanitarian activities and cultural diplomacy as a way to find solution in the territorial dispute. Humble hard power can't be defined solely in pluralism or solidarism perspectives that we need to see this concept as a middle way of pluralism and solidarism.

\section{Conclusion}

The Philippines had a major victory against China South China Sea Arbitration under the United Nations Convention on the Law of the Sea. But the implications go beyond the bilateral dispute between China and the Philippines and it carries deep question of the efficacy of international law in the international politics as well as the solidarism in International Relation theory.

The UNCLOS arbitration tribunal's decision will be a foundational moment in determining the primacy of international law, in the contemporary effort to find law-based solutions to international crises, and even in the new world order with a rising China. What we expect that the UNCLOS tribunal is an admirable call for the supremacy of international law, and the further implementation of other lawbased answers. Yet the analysis above demonstrates that these declarations may be more limited than is widely expected, and also may have a more fragile basis due to the domination of power politics approach in China foreign policy.

The pluralism approach is more relevant in discussing recent phenomena of South China Sea issue. As discussed earlier, solidarism has failed in explaining the aggressiveness of states that prevent the implementation of the international law. Solidarism has failed bringing arguments supporting the reverse phenomena of 
legalization. Meanwhile pluralism has its advantage of the power political approach by placing great power politics above the international law. The transformation from international law of Aquino foreign policy to pragmatic approach in Duterte foreign policy reflects the changing dominant perspective from solidarism to pluralism.

\section{Bibliography}

\section{Books}

Abbot, K. et al. (2006). The Concept of Legalization. In: International Law and International Relations. Cambridge: Cambridge University Press

Bull, H. (1977). The Anarchical Society: A Study of Order in World Politics. Basingstoke: Palgrave.

Buzan, B. (2004). From International to World Society: English School Theory and the Social Structure of Globalisation. Cambridge: Cambridge University Press.

Cáceres, S. B. (2014). China's Strategic Interest in the South China Sea: Power and Resources. Oxon: Routledge.

Dupont, A., (2014). Maritime Disputes in the South China Sea: ASEAN's Dilemma. In: Perspectives on the South China Sea: Diplomatic, Legal and Security Dimensions of the Dispute. Boulder: Rowman \& Littlefield, pp. 45-52.

Gewirtz, P. (2016). Limits of the Law in the South China Sea. Washington: Brookings. Hurrell, A. (2007). On Global Order: Power, V alues and the Constitution of International Society. Oxford: Oxford University Press.

Johnson, A. N. (2012). A Bilateral Analysis of the South China Sea Dispute: China, the Philippines, and the Scarborough Shoa. Miami: Florida International University.

Wheeler, N. (2000). Saving Strangers: Humanitarian Intervention in International Society. Oxford: Oxford University Press.

Wight, M. (1992). International Theory: The Three Tradition. New York: Holmes \& Meier.

\section{Journals}

Jones, H. L. (2012). Why Comply? An Analysis of Trends in Compliance with Judgments of the International Court of Justice Since Nicaragua. Journal of International and Comparative Law, Volume 12, pp. 58-98. 
Yasuaki, O. (2003). International Law in and with International Politics: The Functions of International Law in International Society. European Journal of International Law, 27(3), pp. 105-139.

Yergin, D. (2006). Ensuring Energy Security. Foreign Affairs, 85(2), pp. 69-82.

\section{Website}

Guardian. (2017). Trump risks 'war' with Beijing if US blocks access to South China Sea, state media warns. [Online] Available at: https://www.theguardian.com/world/2017/jan/13/trumprisks-war-with-beijing-us-blocks-access-south-china-sea-state-media [Accessed 4 May 2017].

Heydarian, R. J. (2016). Philippines: Rodrigo Duterte's pivot to China. [Online] Available at: http://www.aljazeera.com/indepth/opinion/2016/10/philippinesrodrigo-duterte-pivot-china-161012062518615.html [Accessed 20 May 2017].

Hsu, S. (2016). China's Energy Insecurity Glaring In South China Sea Dispute. [Online] Available at: https://www.forbes.com/sites/sarahsu/2016/09/02/chinaenergy-insecurity-south-china-sea-dispute/\#33b138b42eec

[Accessed 23 May 2017].

Kipgen, N. (2017). The Philippines' South China Sea Flip-Flop. [Online] Available at: http://thediplomat.com/2017/03/the-philippines-southchina-sea-flip-flop/

[Accessed 3 May 2017].

Klein, J. (2016). South China Sea: UN Law of the Sea Arbitration Tribunal Sinks the Rule of Law. [Online] Available at: https://www.foreignpolicyjournal.com/2016/08/20/southchina-sea-un-law-of-the-sea-arbitration-tribunal-sinks-the-rule-of-law/ [Accessed 3 May 2017].

Reuters. (2017). Duterte says China's Xi threatened war if Philippines drills for oil. [Online] Available at: http://www.reuters.com/article/us-southchinasea- 
philippines-china-idUSKCN18F1DJ

[Accessed 20 May 2017].

Rothwell, D. (2016). A finding China can't ignore: the South China Sea arbitration. [Online] Available at: https://www.aspistrategist.org.au/finding-china-cantignore-south-china-sea-arbitration/

[Accessed 13 May 2017].

The Jakarta Post (2016). Indonesia urges parties to respect laws following South China Sea ruling.

[Online]

Available at:

http://www.thejakartapost.com/seasia/2016/07/12/indonesia-urgesparties-to-respect-laws-following-south-china-sea-ruling.html [Accessed 20 May 2017].

The Washington Post. (2016). Beijing's claims to South China Sea rejected by international tribunal.

[Online]

Available at: https://www.washingtonpost.com/world/beijing-remainsangry-defiant-and-defensive-as-key-south-china-sea-tribunal-rulinglooms/2016/07/12/11100f48-4771-11e6-8dac0c6e4accc5b1_story.html?utm_term=.7d19ebc0bb1c [Accessed 14 May 2017].

Townshend, A. (2016). Beijing rejects tribunal's ruling in South China Sea case. [Online] Available at: https://www.theguardian.com/world/2016/jul/12/philippines-winssouth-china-sea-case-against-china [Accessed 2 May 2017].

Ünver, H. A., (2016). Energy Security in the South China Sea. [Online] Available at: http://risingpowersproject.com/energy-security-southchina-sea/

[Accessed 2 April 2017].

Xiaoming, L. (2016). South China Sea arbitration is a political farce. [Online] Available at: http://www.telegraph.co.uk/news/2016/07/23/southchina-sea-arbitration-is-a-political-farce/ [Accessed 3 May 2017]. 
Zhang, F. (2016). Breathtaking but counterproductive: the South China Sea arbitration award. [Online]

Available at: https://www.aspistrategist.org.au/breathtakingcounterproductive-south-china-sea-arbitration-award/

[Accessed 3 May 2017]. 